\title{
Scrutinized: The TRIPS Agreement and Public Health
}

\author{
Junaid Subhan*
}

\section{SUMMARY}

The World Trade Organization's (WTO's) Agreement on Trade-Related Aspects of Intellectual Property Rights (TRIPS) of 1994 seeks to implement a uniform set of intellectual property protection across member nations to provide greater stability in international economic relations. Critics argue that the TRIPS agreement provides unnecessarily strong protection of intellectual property rights which serves to prevent the ill in developing nations from having access to affordable essential medications.

The first recommendation that this paper makes is to provide two sets of intellectual property protection, one that applies to essential medications such as AIDS drugs and certain antibiotics and another that applies to drugs that treat non-life threatening conditions.

The second recommendation builds upon the first recommendation: if two sets of intellectual property protection legislation are enacted, patents on essential medications should be restricted to patents on processes rather than the product itself.

The third recommendation seeks to amend the language of the TRIPS agreement to make it obligatory for member nations to implement provisions on compulsory licensing within their domestic legislation.

\section{INTRODUCTION}

At the junction of the medical sciences, public health, economics, political science, business and law lies a fascinating crisis facing much of the developing areas of the world. The question of providing access to essential medications for the third world is a complex one and faces many barriers to a solution. Diseases like AIDS, malaria, and tuberculosis have been ravaging the developing world for decades; despite the efforts of NGO's, governments, health professionals, lawyers and even major pharmaceutical companies, a solution to these problems is nowhere in sight.

Socio-political factors play an important role in the rampant spread of disease in underdeveloped nations. The scarcity of basic infrastructure in developing nations, such as roads and transportation for access to

\footnotetext{
*To whom correspondence should be addressed: Junai Subhan e-mail: junaid_six@hotmail.com
}

hospitals, the neglect of the typically substantial rural population and basic sanitation to prevent the spread of disease, are all concerns that must be addressed to quell the public health crises facing these countries. Government instability, corruption and inefficiency are factors that exacerbate the situation (1).

Scientific and medical problems are an added burden on developing nations. Cures for some of the most devastating diseases such as AIDS and malaria are unavailable. Prevention strategies are falling on deaf ears due to time-honored views and social stigma. With a few exceptions, inadequate education of the public serves to perpetuate these counter-productive notions. The lack of health care professionals to administer sophisticated drug regimens and ensure proper compliance with prescriptions is a further challenge (2). The commercial side of this issue cannot be ignored. Pharmaceutical companies are just that, they are commercial entities and as such have a profit motive. 
Although the ethics of their position can be endlessly argued, they view their primary responsibility to be towards their shareholders and investors. Consequently, the pharmaceutical industry has concentrated their research and development efforts in areas that are likely to be profitable, such as drugs for conditions prevalent in developed regions. Malaria, schistosomiasis and other such conditions do not present the potential for lucrative returns and so are often neglected in commercial research.

Of all the challenges facing developing nations with respect to public health, none has garnered nearly as much attention as the legal facet of the problem. It has been repeatedly argued on one side that stringent intellectual property legislation keeps drug prices too high and as a result makes them less accessible to those who need them the most (3). The other side contends that intellectual property laws are required to foster innovation and create reward incentives for pharmaceutical companies to invest in risky research and development (4). This paper will examine the underpinnings of globalized intellectual property law and its effect on developing nations and make three recommendations that seek to better implement public health concerns into the existing legal framework.

\section{BACKGROUND}

\section{WTO}

The World Trade Organization is the body that regulates international trade amongst its member nations. It is the only such organization in the world and thus has tremendous influence over international trade policy. While bilateral and multilateral free trade agreements exist and are permitted under the provisions of the WTO, no other agreement has been as much of a driving force behind the globalization and liberalization of trade barriers as the set of agreements that comprise the WTO. The WTO allows representatives of member countries to come together to form the agreements that are central to the functioning of the WTO and the expansion of global trade. There are three such agreements: GATT (the General Agreement on Tariffs and Trade), GATS (the General Agreement on Trade in Services) and the TRIPS (Trade-Related Aspects of Intellectual Property Rights) agreement (5).

\section{TRIPS}

The TRIPS agreement has played a central role in the debate on providing access to essential medications to countries of the developing world. TRIPS is a WTO agreement that was negotiated in the Uruguay Round of negotiations from 1986 to 1994 by the members of the WTO ( $80 \%$ of the world's nations and the vast majority of the world's trading nations) that sets out certain rules regarding intellectual property rights (5). Once the member countries agree to the provisions, it becomes an official agreement of the WTO that must be ratified by member country governments in their own parliaments. The effect of this is to create a world standard of intellectual property protection. Agreements ratified by the WTO set out certain minimum standards; member countries reserve the right to go above and beyond the provisions of the agreements as long as domestic legislation does not controvert the conditions set out by the WTO agreements.

The purpose of the TRIPS agreement is to establish a uniform set of rules across the globe that would provide adequate standards of protection for intellectual property and provide greater predictability and stability in international economic relations (5). At this point it is important to note that the TRIPS agreement applies to all forms of intellectual property: from copyrights to trade secrets, however, this paper will focus on the TRIPS agreement as it relates to patent protection; and its impact on the accessibility of medications. The regulation of intellectual property rights has not always been of primary importance in the international arena. In the latter half of the twentieth century, the proliferation of high-technology devices, and the means to reproduce them at low relative cost, has made it essential to preserve an environment that encourages innovation. Industries that invested heavily in research and development, such as the information technology industry, were seeing their work pirated by other companies and sold for a fraction of the price offered by the inventors. This created an environment that was more profitable to "second-movers" as opposed to firstmovers ${ }^{1}$ and thus heavily discouraged innovation. Before the enactment of the TRIPS agreement, international intellectual property rights were governed by the Paris Convention on the Protection of Industrial Property which was first drafted in 1883 . It was widely recognized in economic and commercial circles that the Paris Convention was inadequate to address modern issues of concern in industries such as information technology and biotechnology: there were few rules dealing with patents, no minimum period of patent protection, and no mention of the exclusive rights of patent-holders. The TRIPS agreement was the modernday solution to this problem; it took, as its foundation, the provisions of the Paris Convention and the majority of the provisions of the Berne Convention for the Protection of Literary and Artistic Works. To this foundation, the TRIPS agreement added several other

\footnotetext{
1 "First-movers advantage" is a fundamental commercial principle that states that the first company to fill a market segment enjoys a significant competitive advantage over future competition
} 
specifications that addressed the inadequacies outlined above (5). Any nation that wanted to take part in the World Trade Organization was obliged to amend its intellectual property legislation to meet the guidelines set out in the agreement, thus creating a uniform international standard of protection for intellectual property rights.

The provisions of the TRIPS agreement range from the mundane to the controversial. Included in its terms is a minimum period of patent protection of twenty years from the date of filing for a patent. Significantly, the TRIPS agreement also invalidates the use of process patents by declaring that patent protection on a process extends to the product of that process. In addition to these provisions, the TRIPS agreement sets out two mechanisms that deal with international public health crises: compulsory licensing and parallel imports (5).

\section{Compulsory licensing}

Under article 31 of the TRIPS agreement (6), the rights of patent holders can be circumvented in certain situations. More specifically, member governments are given the authority to grant a license to a party willing to commercialize an invention protected under patent without the consent of the patent holder. Unless there is a "national emergency", the proposed licensee is required to make reasonable efforts to seek a voluntary license (6). If the patent holder refuses to grant a license, a non-exclusive license can be granted by the government. Consequently, subject to other provisions of the TRIPS Agreement, compulsory licensing allows generic drug companies to manufacture patented drugs and sell them at a fraction of the price that the patent holders would, since only the costs of producing the medication and not the costs of research and development need to be recovered. Critics of the compulsory licensing provisions point to paragraph (f) under the same article which specifies that compulsory licensing must be used "predominantly for the supply of the domestic market of the Member authorizing such use" (6). These critics contend that this clause makes it exceedingly difficult for governments of developing nations to issue compulsory licenses to quell public health crises because it would require that the drugs be manufactured in developing countries where little infrastructure exists to support this ultra-sophisticated industry (7).

\section{Parallel importing}

Parallel imports allow a developing nation to take advantage of the common practice of differential pricing of drugs across different countries. For instance, if a package of Nevirapine, a patented drug, is being sold at $\$ 250.00$ in France and at \$275.00 in South
Africa, a South African company (or the government itself) can import the drug from France and sell it at a lower price without the authorization of the South African patent holder. Parallel imports effectively allow countries to purchase patented medications at the lowest global price. The right to parallel import under the TRIPS agreement is based on a fundamental legal principle called "exhaustion" of intellectual property rights which defines the point at which a patent holder ceases to have exclusive rights in the context of re-sale of its product (5). Article 6 of the agreement states that member countries can independently decide at which point the exclusive rights of patent holders with respect to re-sale are terminated, but issues of exhaustion cannot form the basis of a dispute brought to the WTO for resolution. In effect, article 6 of the TRIPS agreement allows member countries to engage in parallel importing.

\section{Doha declaration on TRIPS and public health}

Although these provisions were in the TRIPS agreement since its inception, nations never interpreted the provisions of the agreement in a manner consistent with the promotion of public health. Certain nations that were subject to the TRIPS agreement would enact legislation that maximized the protection of intellectual property rights but ignored public health crises affecting developing areas. Further and perhaps even more damaging, at the behest of the influential pharmaceutical lobby developed nations would threaten sanctions on countries that attempted to take advantage of parallel importing or compulsory licensing. For example in 1997, the United States notoriously threatened trade sanctions against South Africa unless they repealed a section of the Medicines and Related Substances Control Amendment Act which allowed compulsory licensing and parallel importing, despite it being TRIPS compliant $(3,8)$.

It was these events that drew the ire of public health advocates worldwide. At this point the WTO acknowledged the weaknesses inherent in their agreement and recognized that the TRIPS agreement must be interpreted and applied in a manner that took into consideration the health care crisis facing the developing world.

On November 14, 2001 in Doha, Qatar a historic declaration was made by the WTO. The member governments agreed on an independent declaration relating to the TRIPS agreement and its role in alleviating public health crises worldwide (9). There were three primary concerns about the TRIPS agreement that were addressed by the Doha Declaration (5). First, there were doubts as to whether the member nations would interpret the TRIPS agreement in a 
manner that favoured the advancement of public health. To address these doubts, in paragraph 4 of the Declaration, the member nations asserted the Agreement's compatibility with public health and the right of member nations to interpret the agreement with the aim of improving public health crises.

Second, concern was expressed about the pressure being placed on developing nations to omit TRIPS measures that favour public health from their legislation. To allay this concern, it is reiterated in numerous instances throughout the Declaration that nations have the autonomy to enact their own legislation without influence from external actors. Although redundant declarations without concrete steps forward may seem inconsequential, it is customary in international law to first build consensus on certain principles and then eventually move nations to adopt policies consistent with those principles (10).

Third, and most importantly, the practicality of the provisions on parallel importing and compulsory licensing were questioned. In paragraph 5 (d), it was clarified that member nations have the right to engage in parallel importing, in particular, without interference from external actors. A further concern, as previously mentioned, was that compulsory licensing would only be allowed if it was used to supply the authorizing country's domestic market. This meant that developed nations could not authorize compulsory licenses for the supply of medications to developing countries. A compulsory license could only be used to supply a developing nation if the proposed licensed product was manufactured in its jurisdiction (11). The difficulty with this situation is that developing nations rarely have the infrastructure required to support a stable pharmaceutical industry. Paragraph 6 of the Declaration (9) addresses this:

\footnotetext{
"We recognize that WTO Members with insufficient or no manufacturing capacities in the pharmaceutical sector could face difficulties in making effective use of compulsory licensing under the TRIPS Agreement. We instruct the Council for TRIPS to find an expeditious solution to this problem and to report to the General Council before the end of 2002."
}

\section{Doha assignment}

Paragraph 6, called the Doha Assignment, was clearly the most progressive aspect of the Doha Declaration; it called for a revision of one of the TRIPS agreement's greatest obstacles to access to medication. Unfortunately, the WTO was unable to come to an agreement by the end of 2002 (5).

Criticism of the WTO mounted because of their perceived complacency in dealing with a change that would affect the lives of millions; but they finally came through on August 30, 2003 with a consensus on how to improve the compulsory licensing system (12). Under the agreement, all least developed countries ${ }^{2}$ that are WTO members will be exempted from the requirement of themselves producing patented drugs under compulsory license. Furthermore, countries that fall outside the least developed country definition can issue a compulsory license (if the drug is patented in its jurisdiction) for the supply of a developing country if that country's public health situation falls under certain criteria:

$$
\begin{aligned}
& \text { - Evidence of a public health concern } \\
& \text { Evidence that the importer's pharmaceutical industry } \\
& \text { is non-existent or inadequate. } \\
& \text { - Proof that the drug will be used only for public, non- } \\
& \text { commercial purposes. }
\end{aligned}
$$

It was further stated in paragraph 11 of the agreement that amendments to the TRIPS Agreement to reflect these decisions would be made by June of 2004; thus giving it full legal force at that time. ${ }^{3}$

In a press release, WTO Director-General Supachai Panitchpakdi called this decision a "historic agreement". Panitchpakdi further elaborated: "It proves once and for all that the [WTO] can handle humanitarian as well as trade concerns. This particular question has been especially difficult. The fact that WTO members have managed to find compromise on such a complex issue bears testimony to their goodwill." (5) Leaders across the developed world touted the decision as a spectacular development in international intellectual property law. Kofi Annan, the UN Secretary-General, stated that "intellectual property protection is key to bringing forward new medicines, vaccines and diagnostics urgently needed for the health of the world's poorest people. The United Nations fully supports the TRIPS agreement - including the safeguards incorporated within it." (13)

\section{RECOMMENDATIONS}

The TRIPS agreement is the sweet spot on the punching bag that is the World Trade Organization. Fairly or not, the TRIPS agreement is alleged to be a monstrosity of modern capitalism. Says Noam Chomsky, a renowned academic: "There is nothing

2 Least developed country (LDC) as defined by the UN. Of the 50 LDC's, 32 are WTO members.

3 The June deadline passed without any consensus, the deadline was then extended to March of 2005. The March deadline also passed without any agreement, however on the 6th of December 2005, the WTO finally came to a consensus on the amendment to be made to the TRIPS Agreement. This amendment follows the principles agreed to on the 30th of August 2003. Member nations have until the 1st of December 2007 to ratify the amendment so that it can be formally included into the TRIPS Agreement. 
liberal about [the TRIPS agreement]. It is a highly protected system, designed to ensure that private tyrannies, which is what corporations are, monopolize the technology and the knowledge of the future." (14) Dr. Zafar Mirza, Executive Coordinator of The Network, a Pakistani health advocacy group, asks "They are talking about harmonizing trade policies, but nobody is saying a word about harmonizing the socioeconomic conditions of the world. All countries are at different stages of development, how could they be governed by the same law?" (15) These comments stand in stark contrast to those quoted above by highprofile public officials. Why is one group so staunchly opposed to the TRIPS agreement, while another shows seemingly infallible support? The second part of this paper seeks to reconcile these two views.

Criticism of the TRIPS agreement arises on a number of levels. There are those who criticize the implementation of its provisions in sovereign countries, there others that criticize the provisions of the TRIPS agreement and there are still others who criticize its very existence. The subsequent critique of the TRIPS agreement will be made through the lens of the following neutral principles in order to make the recommendations as relevant and applicable to the current situation as possible:

\footnotetext{
Access to essential medications is a fundamental human right. 4

- Intellectual property legislation has been a driving force behind innovation for commercial purposes. ${ }^{5}$

- The world's primary source of novel and generic drugs has been and will continue to be the commercial pharmaceutical industry. 6

- $\quad$ The TRIPS agreement will not be repealed in the near future and will continue to shape international intellectual property law. 7
}

Access to essential medications is a fundamental human right and as such, it trumps all other claims in this issue. The reason this issue is so complex and so hotly debated is that in order to satisfy this right, the right must be conceded. In other words, in order to finance the development of essential medications, the producers of these medications must be financially compensated from the users of the medications who, in this case, cannot afford them. In theory, since access to essential medications is a fundamental human right, those who cannot afford these medications should have them provided at no cost or at a reasonable cost. From the above argument, the problem facing the TRIPS agreement in the context of global public health is defined: the fundamental human rights of those in the developing world must be respected without hindering the development of novel medications that serve to advance the satisfaction of this right.
The following recommendations keep the above arguments front and centre and attempt to improve the public health situation within the framework of the existing TRIPS agreement.

\section{Recommendation 1: Define the term "essential medication" within TRIPS.}

Patents can be applied to a wide variety of technologies; from the most complex and sophisticated piece of computer software to the most mundane hinge, nut or bolt. Even within the pharmaceutical industry, products under patent vary greatly. With this immense variance, should a patent on a drug for AIDS be treated in the same way as a patent on a drug for erectile dysfunction or high cholesterol?

A wide array of drugs are developed and manufactured by pharmaceutical companies and the TRIPS agreement must differentiate between patents for Viagra and patents for Efavirenz. It is reasonable to demand full 20-year intellectual property protection for "chemical toys" (17) but when it comes to life-saving essential medications certain concessions in favour of the promotion of public health must be made. The term "essential medication" should be defined under the TRIPS agreement, not in reference to a list of diseases, as has been proposed in the past (18), but rather as a general description of what constitutes the difference between an essential and a non-essential drug. Possible criteria for inclusion into such a category would be:

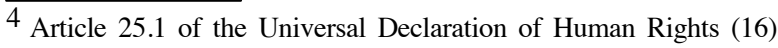
states: Everyone has the right to a standard of living adequate for the health and well-being of himself and of his family, including food, clothing, housing and medical care and necessary social services, and the right to security in the event of unemployment, sickness, disability, widowhood, old age or other lack of livelihood in circumstances beyond his control.

Article 28 of the Declaration further asserts:

Everyone is entitled to a social and international order in which the rights and freedoms set forth in this Declaration can be fully realized.

5 This claim is more or less incontrovertible; executives of the pharmaceutical industry, officials of the UN and the WTO, NGO's lobbying against TRIPS and other detractors wholeheartedly agree on this principle according to all sources researched.

6 The "commercial pharmaceutical industry" includes generic drug companies as well as research \& development based drug companies. Though recently a few enterprises have been receiving publicity for their innovative approach to financing the research and development of neglected diseases, they are exceptional cases. Presently, the vast majority of the world's supply of drugs comes from the commercial pharmaceutical industry. This does not seem likely to change in the near future.

7 This statement is irrefutable and redundant but will play an important role in the critique. Its function is to narrow the scope of the critique to the provisions and implementation of the TRIPS agreement itself and not its existence, nor factors outside of its jurisdiction. The idea is to make the recommendations directly applicable to the current legal framework. 
availability of alternative treatment, severity of the disease the medication is aimed at treating, and the capacity of the patent-holder to adequately supply markets that demand the patented product. For separate definitions to be beneficial though, separate provisions should be made where appropriate. Ideally, two separate sets of patent legislation would exist in parallel; one applying to medications deemed essential and another applying to non-essential medications.

By creating separate categories of drugs, the TRIPS Agreement can more properly balance intellectual property protection of drugs with their purpose of healing as many of the ill as possible. Such a system can encourage innovation by increasing the potential rewards of a successful discovery of a non-essential medication. Simultaneously, access to essential medications by patients in developing areas can be improved by placing fewer protections on the intellectual property behind these medications.

There is, however, one glaring problem with this recommendation; creating a two-tiered system of intellectual property protection, where one set of drugs is given stronger protection than the other, will likely drive research investment into the more strongly protected class of drugs. The solution to this is surprisingly simple: because two classes of drugs are established, additional rewards that do not interfere with access can be implemented in the class of drugs that is less protected. For example, patents on essential medications could be restricted to process patents alone; in exchange, duration on a process patent could be extended beyond twenty years. Because two separate categories of drugs are defined, product patents would be maintained on all patentable goods other than essential medications, including non-essential drugs.

In effect, creating separate categories of intellectual property protection for disparate classes of drugs allows for customized protection that can both promote innovation and uphold the fundamental human rights of those in need of essential medications.

\section{Recommendation 2: Allow process patents}

Two types of patents exist: process patents and product patents. Process patents are those that apply to the method of making or manufacturing an invention. This stands in contrast to a product patent which is a patent on the good itself (the product of the process). Under a product patent, a particular invention is protected regardless of the method used to manufacture it, on the other hand, under a process patent only the particular method for making the product is protected. It then follows that a process patent affords its holder less protection on its intellectual property than a product patent.
To implement this recommendation, paragraph (b) of article 28.1 of the TRIPS agreement, which states the rights of process patent holders, would need to be amended. This paragraph states that the rights of a process patent holder extend to the product obtained from the process and are not restricted simply to the process itself, thus effectively eliminating the notion of process patents from the TRIPS agreement (6).

The most appealing aspect of process patents is that they are at the very core of what capitalism represents: competition, efficiency and profitability; yet applied in the correct way, they can be extremely beneficial to patients in the developing world. Most research-based pharmaceutical companies would likely disagree with this view and would argue that a process patent provides little incentive to invest in risky research because another company can simply reverse engineer a medication to find an alternative method of producing the product, thus bypassing the process patent. However, process patents in this situation can prove to be acceptable to research-based pharmaceutical companies and can improve the public health situation in developing areas.

Process patents provide a lower standard of intellectual property protection and thus encourage competition which in turn serves to decrease market prices. If a product is under a process patent, it encourages competing companies to invest in research to develop a method of producing the product in question more efficiently than the current standard. Unless the newly developed method is more efficient and cost-effective, the developing company would not be able to commercialize the product because the more efficient and cheaper product would be preferred by consumers (and third-world governments). Hence, a process patent inherently encourages the development of the most efficient and cost-effective method of producing the patented product, theoretically resulting in lower prices.

The drawback of process patents (and the likely reason they are barred from use under the TRIPS agreement) is that they only allow research-based pharmaceutical companies to maintain a patent monopoly until a second developer finds a more efficient way to produce the drug. This would typically shorten the period of patent monopoly that the discovering company is entitled to; however it provides other companies with an opportunity to earn increased profits by improving on the drug in question. In order to make the notion of process patents more amenable to research-based pharmaceutical companies (and thus more agreeable to the more powerful member nations), a few modifications must be made to this recommendation. First, process patents should be 
applicable only to essential medications, as described in the first recommendation, to encourage research and development expenditure in other drug classes and in other technologies altogether. Secondly, to preserve some incentive for research in the field, certain restrictions should be placed against the second developer in commercializing its product in areas in which the discovering company holds a substantial proportion of the market.

In combining the above provisions, the result could be a highly efficient drug discovery and manufacturing process protected by patent, but flexible enough to adequately supply developing areas of the world.

Recommendation 3: Compulsory licensing: an obligation not an option.

The biggest problem with compulsory licensing, as described in the TRIPS agreement and its amendment, is that it is not written as a minimum standard that nations must implement into their domestic legislation to be TRIPS-compliant. Rather, it is written as an option that member nations have for implementation into their domestic legislation. As a result, only five jurisdictions that have the pharmaceutical capacity to be exporting countries under compulsory licensing have actually made progress on implementing these measures into their domestic legislation (18). If the Doha Declaration is considered to be an accurate reflection of the sentiments of nations, provisions on compulsory licensing must be incorporated into the TRIPS agreement as an obligation on member nations. At the very least, if separate classes of drugs are created, as outlined in the first recommendation, provisions on compulsory licensing for essential medications should be made a requirement in order to be TRIPS-compliant.

Article 31 of the TRIPS agreement specifies the conditions of use of compulsory licensing by member nations. It begins by stating "Where the law of a Member allows for other use of the subject matter of a patent without the authorization of the right holder" (6) in reference to compulsory licenses. The language of the article clearly leaves it possible for member nations to enact domestic intellectual property legislation without provisions for compulsory importing and yet still be compliant with the TRIPS agreement, the Doha Declaration and the Decision of August 30, 2003. The notion of compulsory licensing has very little value to public health if the only nations that adopt it are the ones that have no capacity to manufacture pharmaceutical products. Although it is true that parallel importing is also worded to be an option rather than an obligation, it does not pose as serious a problem because for a country to benefit from parallel importing, it must only amend its own domestic legislation to allow it; it is not dependent on the cooperation of other nations. On the other hand, a developing nation can only benefit from compulsory licensing if more developed nations enact it into their own legislation.

Detractors of this recommendation may argue that making these provisions obligatory, encroaches upon the sovereignty of a nation; but this must be looked at in the context of the TRIPS agreement as a whole. The agreement makes several provisions obligatory: patent protection must last for at least 20 years; process patenting is not permissible, public disclosure of the invention is obligatory, and so on. Making compulsory licensing obligatory in the context of a supra-national agreement that makes other provisions obligatory, particularly when it is consistent with an official declaration of the member nations, should elicit little political opposition on these grounds.

\section{CONCLUSION}

In conclusion, it must be reiterated that the lack of accessibility to essential medications by developing nations is a result of a number of factors; an unprecedented level of international collaboration and empathy will be required to make meaningful progress on this issue. This paper though, focuses on the factor that has been receiving the most attention: the WTO and its TRIPS agreement. The reason this facet of the problem is emphasized in this paper is three-fold:

- Of the many factors contributing to the current public health crisis, none are as simple to resolve, relatively speaking, than amending the TRIPS agreement.

- $\quad$ From my research, I have concluded that there are means that have yet to be addressed to balance the interests of commercial pharmaceutical enterprises with the human rights of patients in developing nations with.

- There is reason to be optimistic about the TRIPS agreement. The Doha Declaration, which affirms the commitment of WTO members to improving public health in developing nations is only five years old, this is a very short period of time in which to expect sweeping changes in international law. By lobbying our governments with creative yet pragmatic ideas, globally equitable healthcare can be a reality.

\section{REFERENCES}

1. Handelman H. The Challenge of Third World Development. Upper Saddle River: Prentice Hall; 2003.

2. Novak K. The WTO's Balancing Act. Journal of Clinical Investigations 112: 1269-1273; 2003.

3. Oh C. TRIPS and pharmaceuticals: A Case of Corporate Profits Over Public Health. Editorial. Third World Network

4. Striking a Balance: Patents and Access to Drugs and Health Care. Editorial. World Intellectual Property Organization

5. World Trade Organization Website. <http://www.wto.org>. 
6. World Trade Organization. TRIPS Council. Trade-Related Aspects of Intellectual Property Rights (TRIPS); 1994.

<http://www.wto.org/english/docs_e/legal_e/27-trips.pdf>.

7. Kohr M. The WTO, the Post Doha Agenda and the Future of the Trade System. Third World Network; 2002. $<$ http://www.twnside.org.sg/title/mkadb.htm>.

8. International Intellectual Property Institute. Patent Protection and Access to HIV/AIDS Pharmaceuticals in Sub-Saharan Africa. World Intellectual Property Organization; 2000. <http://www.wipo.int/about-ip/en/studies/pdf/iipi_hiv.pdf>.

9. World Trade Organization. Doha Ministerial Declaration on TRIPS and Public Health; 2001. $<$ http://www.wto.org/english/thewto_e/minist_e/min01_e/mind ecl_trips_e.pdf>.

10. Brynen, Rex. Department of Political Science, McGill University. Personal interview; 23 Mar. 2005.

11. Correa CM. Implications of the Doha Declaration on the TRIPS Agreement and Public Health. World Health Organization; 2002.

12. World Trade Organization. TRIPS Council. Decision of 30 August 2003; 2003. $<$ http://www.wto.org/english/tratop_e/trips_e/implem_para6_e. $\mathrm{htm}>$.

13. Annan K. Interview. World Health Organization; 2001. $<\mathrm{http}$ //www.who.int/inf-pr-2001/en/pr2001-19.html>.

14. Chomsky N. Speech. Asian College of Journalism, Chennai. $<$ http://www.greenmac.com/World_Events/aninterac.html $>$.
15. Rizvi M. TRIPS Will Push Health Care Beyond Poor. Editorial. Third World Network <http://www.twnside.org.sg/title/beyondcn.htm>

16. United Nations. Universal Declaration on Human Rights; 1948. $<$ <ttp://www.un.org/Overview/rights.html>.

17. Bello W. Speech. XV International AIDS Conference, Bangkok; 2004. <http://www .alternatives.ca/article1363.html>.

18. Elliott R. Doha Para 6 Implementation: EU Proposal vs. Canadian Legislation. Online posting; 2004. $<$ http://lists.essential.org/pipermail/ip-health/2004November/007091.html>.

19. Amir A, Gillespie-White L. Do Patents for Antiretroviral Drugs Constrain Access to AIDS Treatment in Africa? Journal of the American Medical Association 286: 1886-1892; 2001.

20. Consumer Project on Technology. <http://www.cptech.org>.

21. Boelaert M, Lynen L, Van Damme W, Colebunders R. Do Patents Prevent Access to Drugs for HIV in Developing Countries? Journal of the American Medical Association, Letters 287; 2002.

22. Goldberg RM. Fight AIDS With Reason not Rhetoric. The Wall Street Journal, 23 Apr. 2001.

23. The International Guidelines on HIV-AIDS and Human Rights; 2002. <http://www.icaso.org/docs/JFAP\%20-\%20Web.pdf>.

24. Weissman R. AIDS and Developing Countries: Democratizing Access to Essential Medicines. Foreign Policy in Focus; 1999.

Junaid Kaleem Subhan graduated from McGill University with a Bachelors of Science degree in Microbiology \& Immunology in June of 2005. He is currently studying finance with the aim of graduating with a Bachelors degree in Commerce in 2007. He would like to pursue law studies in the future. 